\title{
Effect of Olive mill Wastewater and Biochar under Different NPK Rates on Sandy Soil Properties and Peanut productivity
}

\author{
${ }^{1}$ Doaa M. Khalifa and ${ }^{2}$ Ibrahim, M. Elareny
}

\author{
${ }^{I}$ Soils, Water and Environmental Res. Inst., (SWERI), Agriculture Research Center, (ARC) Giza, \\ Egypt. \\ ${ }^{2}$ Field Crops Research Institute, Agricultural Research Center (ARC), Giza, Egypt.
} Received: 05 August 2020 / Accepted 15 Sept. August 2020 / Publication date: 25 Sept. 2020

\begin{abstract}
The field experiment was conducted two successive summer seasons of 2018 and 2019 at Ismailia Agricultural Research Station, Egypt to evaluate the effect of Olive mill wastewater (OMW), Biochar and NPK fertilizers rates on some sandy soil properties and peanut (Arachish ypogaea) productivity in sandy soil. A randomized complete block design was used. The results indicated that soil $\mathrm{pH}$ and EC was not significantly affected in the soil treated with Olive mill wastewater (OMW) and biochar. There are positive significant effects on nutrient availability (NPK) in both seasons by using biochar and olive mill wastewater in soil as well as their content in peanut plants. The application of OMW can improve soil quality indices (nutrients $(\mathrm{N}, \mathrm{P}$, and $\mathrm{K}$ ), organic matter, $\mathrm{pH}$, total porosity, bulk density and plant growth performance. The Olive mill wastewater (OMW) and Biochar application increased plant height, No. of branches, No. of pods, protein (\%), seed oil (\%) and seed yield (ton fed $\left.{ }^{1}\right)$ as well as NPK content in peanut plant.
\end{abstract}

Keywords: Olive mill wastewater, Biochar, NPK, sandy soil, peanut (Arachis hypogaea)

\section{Introduction}

Egypt occupies a total area of about 100 million hectares, out of this area, is about 3.1 million hectares as cultivated area. The newly reclaimed lands ( 0.8 million hectares) included sandy and calcareous soils, which the soil in poor in organic matter and macro-and micronutrients (Abd El-Hadi, 2004). The sandy and calcareous soils faces large constraints due to low water holding and nutrient retention capacity, and accelerated mineralization of soil organic matter, (Abdelraouf et al., 2017).

Olive mill wastewater (OMW) is the liquid waste produced from olive oil production process. The reuse and management of OMW is a major issue in the olive oil-producing regions. An estimated 30 million $\mathrm{m}^{3}$ of Olive wastewater is yearly produced from olive oil process (Ouzounidou and Asfi, 2012). The application of OMW can improve soil quality indices nutrients (N, P, and K), organic matter, $\mathrm{pH}$ and plant growth. Soil nutrient contents, as well as soil physical properties (structure, porosity, density) and hydraulic (saturated hydraulic conductivity), were improved with Olive wastewater application (Kavvadias et al., 2015; Belqziz et al., 2016). OMW chemical properties might cause soil and water contamination. However, it is used in agriculture as soil amendment or fertilizer can be rationalized because of the high content of plant growth nutrients, such as nitrogen $(\mathrm{N})$, phosphorus $(\mathrm{P})$, and potassium $(\mathrm{K})$, organic matter which can contribute positively to plant nutrient requirements especially under arid environment and poor soil fertility conditions (Mohawesh et al., 2014; Belqziz et al., 2016). Piotrowska et al. (2006) found that soil application of OMW increased soil water holding capacity, total soil porosity and aggregate stability density which was attributed to the effect of the soil compounds provided to the soil with OMW application. Ahmed et al. 2020) found growth experiment was performed to test the potential effects of Olive mill wastewater on germination efficiency, growth rate, total dry weight, nutrient content and uptake of Peanut, in sandy clay loam soil under $80 \%$ field capacity water regime.

Biochar (BC) is a carbonaceous residue produced through the thermal breakdown of organic materials under limited conditions of oxygen. Biochar was characterized by hydrophobic groups such cyclic acid anhydrides (C-C and $\mathrm{C}-\mathrm{O})$; asymmetric carboxylates $\left(\mathrm{CO}_{2}\right)$, aromatic ketones $(\mathrm{C}=\mathrm{O})$; silicon (Si-O); and hydrophilic groups such carbonates (C-O) and silanol (Si-O-H). With these

Corresponding Author: Doaa M. Khalifa, Soils, Water and Environmental Res. Inst., (SWERI), Agriculture Research Center, (ARC) Giza, Egypt.

E-mail: doaa.mousa@gmail.com 
classifications, this biochar was determined to have a high hydrophobicity (Duarte et al., 2019). Leonard, (2013) suggested that the biochar is used as a soil amendment for improving soil quality and enhancing carbon sequestration. Biochar is positive improvement of soil physical and hydraulic properties. Khaled and Jeff (2019) reported that the application of biochar led to a decrease in soil $\mathrm{pH}$ and increase in soil OM and CEC. Application rates of biochar can significantly improve soil physical quality in terms of bulk density (BD), and water holding capacity (WHC). However, little data are available on surface area (SA), aggregation stability, and penetration resistance (PR), (Atanu and Rattan, 2013). Biochar is abundant in the organic matter, water holding capacity, nutrient-retaining capacity, and bioavailability nutrition elements (e.g., N, P, K, Ca), (Lehmann and Josehp, 2009). The biochar amendment enhanced the formation and stabilization of the soil macro-aggregates, especially in the sandy loam soil. Aggregate formation and stabilization are affected by the type and amount of organic materials, which include the microorganisms and microbial synthesis (Ouyang et al., 2013). Biochar produced at 300 or $400 \mathrm{Co}$ and added with NPK provided the highest yield compared to that with the NPK alone treatment and also compared to the biochar produced at 500 or $600{ }^{\circ} \mathrm{C}$ treatments (Novak et al., 2009b). Bio-fertilizer plays a substantial role in chemical and biological transformations in soil and maintains soil fertility. The major biological elements, (carbon, nitrogen, oxygen and sulphur) are subjected to comparable cyclic processes. Nevertheless, on top of them is the nitrogen cycle, from both ecological and economic viewpoints (Idriss, 2004). Bio-fertilizers used can either fix atmospheric nitrogen and solubilize phosphate or stimulate plant growth through synthesis of growth promoting substances led to enhancing the decomposition of plant residues to release vital nutrients (Wu et al., 2006). Bio fertilizer application led to improved soil chemical and biological characteristics; moreover due to the use of low doses of chemical fertilizers, agricultural production will be free from contaminants (Salimpour et al., 2010).

Peanut (Arachis hypogaea L.) is one of self-pollinating most essential among edible oil seed crops throughout the world. The peanut is an important food and oilseed crop. It is called as the king of oilseeds crops .Peanut ranks the 13th among food crops, 4th among source of the oil seed crops and the 3rd among source of vegetable protein crops (Taru et al., 2008). It is worth to note that, Egypt is suffering from dramatically shortage in edible oils, needed for nutritional consumption. Although in Egypt, the local production from crop oils is about 340 thousand tons in 2015, the Egyptian consumption is about 2.7 million tons in the same season. This indicated that, there is a major gap (87.4\%) between local production and consumption, which has created importation to fulfill the requirements of market (FAO, 2016). Therefore the objectives of this work were to investigate : the effect of Biochar and Olive mill wastewater (OMW) application on NPK fertilization soil properties and productivity of Peanut plant grown on sandy soil.

\section{Materials and Methods}

A field experiment was conducted at Ismailia Research Station 2019 Agricultural Research Center (A.R.C), Egypt during two successive seasons of winter 2018 and. The soil samples were taken at depth $0-30 \mathrm{~cm}$ before cultivation and after harvesting to determine physical and chemical characteristics of the investigated soil according to Page et al. (1982) as shown in Table (1).

Some properties of the used Olive mill wastewater and bio-char were carried out as described by Brunner and Wasmer (1978) as illustrated in Table 2.

The investigation was conducted to evaluate the effect of biochar, Olive mill wastewater under different NPK rates on soil properties, and productivity of plant peanut grown in sandy soil. The initial soil was analyzed and showed in table 1 soil analysis showed that soil was sandy texture and low fertility for available macronutrients. Biochar and olive mill waste analysis were showed in table 2.The applied biochar to this experiment made of different types of citrus trees it was produced using pyrolysis at a final temperature of $500{ }^{\circ} \mathrm{C}$ with a retention time of $2 \mathrm{~h}$. Biochar samples were ground and sieved at $<0.5 \mathrm{~mm}$ diameter. Biochar was applied to the soil at 4 ton/fed rate while, OMW was applied to the soil at two rates $10 \%$ and $20 \%$ of $50 \mathrm{~L} / \mathrm{fed}$. 
Table 1: Some physical and chemical properties of the initial soil $(0-30 \mathrm{~cm}$ depth).

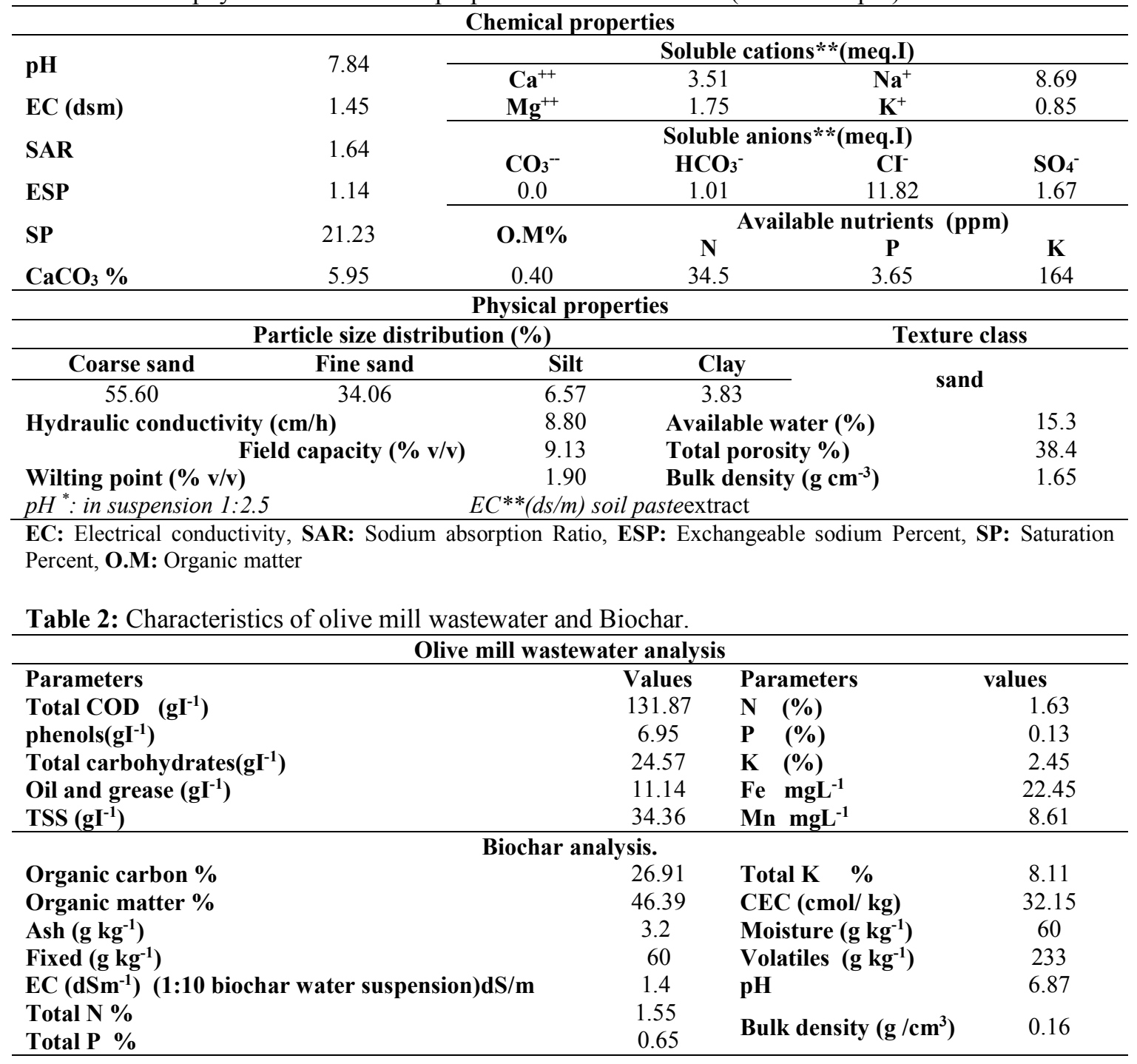

The experiment included 11 treatments with three replicates as follow:

1. Control NPK $(100 \%)$ recommended dose

2. Biochar $(4$ ton/fed $)+$ NPK $_{(50 \%)}$

3. Biochar ${ }_{(4 t \text { ton/fed })}+\mathrm{NPK}_{(75 \%)}$

4. Olive mill wastewater $10 \%(\mathrm{OMW})+\mathrm{NPK}(50 \%)$

5. Olive mill wastewater $20 \%(\mathrm{OMW})+\mathrm{NPK}(50 \%)$

6. Olive mill wastewater $10 \%(\mathrm{OMW})+\mathrm{NPK}(75 \%)$

7. Olive mill wastewater $20 \%(\mathrm{OMW})+\mathrm{NPK}(75 \%)$

8. Olive mill wastewater $10 \%(\mathrm{OMW})+$ Biochar $_{(4 \mathrm{ton} / \mathrm{fed})}+\mathrm{NPK}_{(50 \%)}$

9. Olive mill wastewater $20 \%(\mathrm{OMW})+$ Biochar $_{(4 \mathrm{ton} / \mathrm{fed})}+\mathrm{NPK}(50 \%)$

10. Olive mill wastewater $10 \%(\mathrm{OMW})+$ Biochar $_{(4 t o n / \text { fed })}+\mathrm{NPK}_{(75 \%)}$

11. Olive mill wastewater $20 \%(\mathrm{OMW})+$ Biochar $_{(4 t o n / \text { fed })}+\mathrm{NPK}_{(75 \%)}$

Superphosphate was applied during soil preparation. Ammonium nitrate was added at four split equal doses after 2, 4, 6 and 8 weeks from sowing. Potassium fertilizers were divided into two equal doses, the first was added at sowing after 31 days and the second was added after 55 days from sowing. At harvesting, ten plants from each plot were taken randomly, and threshed. Grain and straw 
were dried using an electrical oven on $75^{\circ} \mathrm{C}$ until constant weight obtained. Then weighted to obtain their dry weight and transferred to seed yield. The grain and straw were ground 0.5 g powder and digested by concentrated digestion mixture of $\mathrm{H}_{2} \mathrm{SO}_{4}+\mathrm{HClO}_{4}$ acids according to Sommers and Nelson (1972). Nitrogen was determined by micro Keldahl, according toPhosphorus was determined by spectrophotometric ally using ammonium moly date stannous chloride method according to Chapman and Pratt (1978). Potassium was determined by a flame photometer, according to Page et al. (1982). Available P and K were extracted by Ammonium-Bicarbonate- according to Soltanpour (1985). Field capacity was determined according to USDA (1962). Soil bulk density, total porosity and saturation percent were determined according to Black et al. (1965).

At harvest, Sample of vegetative growth were taken after 75 days from sowing.Determine the yield components as follows: Plant height $(\mathrm{cm})$, number of branches/plant, and number of pods/plant. Whole plot was harvested and the pods were air dried to calculate seed yield per faddan. Oil and protein yields were calculated per fadden.

The experimental Design was randomized complete block design. Analysis of Variance (ANOVA) and least significant difference (LSD) were calculated according to Gomez and Gomez (1984)

\section{Result and Discussion}

\section{Effect of olive mil wastewater and boichar combined with different NPK rate on soil physical} properties.

1.1. Bulk density, total porosity and hydraulic conductivity.

Data presented in Table 3 showed that application of the biochar and olive mill waste water improved bulk density(BD) values, total porosity (TP) and hydraulic conductivity $\left(\mathrm{K}_{\text {sat }}\right)$ in two seasons compared with control $\left(\mathrm{NPK}_{100 \%}\right)$ recommended dose. The best value of bulk density, total porosity and hydraulic conductivity were $1.37\left(\mathrm{~g} / \mathrm{cm}^{-3}\right), 43.90(\%)$ and $8.49(\mathrm{~cm} / \mathrm{h})$ respectively, in the second season with treatment by biochar + olive mill wastes ${ }_{(20 \%)}+\mathrm{NPK}_{(75 \%)}$ was more than the other treatments. Application of biochar + olive mill wastes ${ }_{(20 \%)}+\mathrm{NPK}_{(75 \%)}$ reduced bulk density and hydraulic conductivity values by percentage 16.4 and $6.1 \%$ respectively, compared with control, while total porosity values was increased by percentage $6.6 \%$ compared with control. These results were agreement with (Arvidsson, 1999).

Table 3: Effect of olive mill wastewater and boichar combined with different NPK rate on soil bulk density (BD), total porosity (TP) and hydraulic conductivity $\left(\mathrm{K}_{\text {sat }}\right)$ in two seasons.

\begin{tabular}{|c|c|c|c|c|c|c|}
\hline \multirow[t]{2}{*}{ Treatments } & \multicolumn{3}{|c|}{ First season } & \multicolumn{3}{|c|}{ Second season } \\
\hline & $\begin{array}{c}\text { BD } \\
\left(\mathrm{g} / \mathrm{cm}^{3}\right)\end{array}$ & $\begin{array}{l}\text { TP } \\
(\%)\end{array}$ & $\begin{array}{c}K_{\text {sat }} \\
(\mathbf{c m} / \mathbf{h})\end{array}$ & $\begin{array}{c}\text { BD } \\
\left(\mathrm{g} / \mathrm{cm}^{3}\right)\end{array}$ & $\begin{array}{l}\text { TP } \\
(\%)\end{array}$ & $\begin{array}{c}\mathbf{K}_{\mathrm{sat}} \\
(\mathrm{cm} / \mathbf{h})\end{array}$ \\
\hline Control (NPK) $(100 \%)$ & 1.68 & 39.9 & 8.70 & 1.65 & 41.6 & 8.69 \\
\hline Biochar + NPK $(50 \%)$ & 1.49 & 40.1 & 8.65 & 1.46 & 42.2 & 8.61 \\
\hline Biochar + NPK $(75)$ & 1.43 & 41.3 & 8.61 & 1.44 & 42.4 & 8.58 \\
\hline Mean & 1.46 & 40.7 & 8.63 & 1.45 & 42.4 & 8.59 \\
\hline $\mathbf{O M W}_{(10 \%)}+\mathrm{NPK}_{(50 \%)}$ & 1.38 & 42.3 & 8.62 & 1.41 & 42.7 & 8.56 \\
\hline $\mathbf{O M W}_{(10 \%)}+\mathrm{NPK}{ }_{(75 \%)}$ & 1.37 & 42.5 & 8.61 & 1.42 & 42.6 & 8.54 \\
\hline OMW $_{(10 \%)}+$ Biochar $+\operatorname{NPK}_{(50 \%)}$ & 1.34 & 42.6 & 8.56 & 1.41 & 42.9 & 8.53 \\
\hline $\mathbf{O M W}_{(10 \%)}+$ Biochar NPK $_{(75 \%)}$ & 1.33 & 42.70 & 8.54 & 1.40 & 43.01 & 8.51 \\
\hline Mean & 1.35 & 42.52 & 8.58 & 1.41 & 42.80 & 8.53 \\
\hline $\mathbf{O M W}_{(20 \%)}+\mathrm{NPK}(50 \%)$ & 1.38 & 42.3 & 8.63 & 1.42 & 43.3 & 8.53 \\
\hline $\mathbf{O M W}_{(20 \%)}+\mathrm{NPK}_{(75 \%)}$ & 1.36 & 42.6 & 8.64 & 1.43 & 43.6 & 8.57 \\
\hline $\mathbf{O M W}_{(20 \%)}+$ Biochar $+\operatorname{NPK}_{(50 \%)}$ & 1.33 & 42.7 & 8.55 & 1.39 & 43.7 & 8.51 \\
\hline $\mathbf{O M W}_{(20 \%)}+$ Biochar $+\operatorname{NPK}_{(75 \%)}$ & 1.32 & 42.90 & 8.50 & 1.37 & 43.90 & 8.49 \\
\hline Mean & 1.34 & 42.6 & 8.58 & 1.40 & 43.6 & 8.52 \\
\hline \multicolumn{7}{|l|}{ LSD. at 0.05} \\
\hline Treatment & 0.36 & 2.11 & 0.22 & 0.293 & 2.3612 & 0.23 \\
\hline OMW Rates & 0.34 & 1.1 & 0.15 & 0.27 & 1.4 & 0.165 \\
\hline Biochar & 0.22 & 0.967 & 0.07 & 0.21 & 0.83 & 0.133 \\
\hline
\end{tabular}


Also, Ndor et al. (2015) mentioned that the applications of biochar had a significant effect on hydraulic conductivity, bulk density, porosity, and soil water-filled pore space. The effect of addition olive mill waste water on soil bulk density indicated a decrease. This reduction in bulk density can be attributed to the dilution effect resulted from mixing olive mill waste water added with the more dense soil minerals (Giovanna et al., 2008). In agreement with these results, the effect appeared to be more obvious for coarse textured soils than fine textured. This may be tended to reduce soils erosion as a result of Bulk density, Total porosity and Hydraulic conductivity improvement (Mekki et al., 2013).

\section{Field capacity, wilting point and available water}

Data presented in Table 4 showed that applications of the biochar and olive mill waste water had positive effect on field capacity values, wilting point and available water in the two seasons compared with control. Where the highest values of field capacity, wilting point and available water were higher with application of biochar + olive mill wastes ${ }_{(20 \%)}+\mathrm{NPK}_{(75 \%)}$ compare with other treatments, while the highest value of available water was with control. Biochar + NPK $(75 \%)$ application increased of field capacity, wilting point and available water by $13.98,6.44$ and $7.54 \%$ respectively, these results were agreement with (Giovanna et al., 2008; Barbera et al., 2013; Adnan and Ghaida, 2015) which reported that addition of (OMW) olive mill waste water was affected on field capacity and witling point depend on texture. The fine-textured soils; the increase in wilting point is less than at field capacity. As a result of sand fraction, the opposite occurred in coarsetextured soils, significant increase in wilting point rather than at field capacity Novak et al., (2009b); Dumroese et al. (2011) found a significant influence of biochar addition on water retention. Addition of biochar increases soil field capacity Albuquerque et al. (2014) and Chan et al. (2007) found that biochar addition increased field capacity Lei \& Zhang (2013) observed a significant increase in plant available water and macro pores in soil amended with biochar.

Table 4: Effect of olive mill wastewater and boichar combined with different NPK rate on field capacity (FC), wilting point (WP) and available water(AW) in two seasons.

\begin{tabular}{|c|c|c|c|c|c|c|}
\hline \multirow[b]{2}{*}{ Treatments } & \multicolumn{3}{|c|}{ First season } & \multicolumn{3}{|c|}{ Second season } \\
\hline & $\begin{array}{l}\text { FC } \\
(\%)\end{array}$ & $\begin{array}{l}\text { WP } \\
(\%)\end{array}$ & $\begin{array}{l}\text { AW } \\
(\%)\end{array}$ & $\begin{array}{c}\text { FC } \\
(\%)\end{array}$ & WP (\%) & $\begin{array}{l}\text { AW } \\
(\%)\end{array}$ \\
\hline Control (NPK) (100\%) & 11.16 & 2.14 & 9.02 & 11.66 & 2.24 & 9.42 \\
\hline Biochar + NPK $(50 \%)$ & 13.01 & 5.56 & 7.45 & 13.33 & 5.60 & 7.73 \\
\hline Biochar + NPK ${ }_{(75)}$ & 13.22 & 5.61 & 7.61 & 13.62 & 5.68 & 7.94 \\
\hline Mean & 13.11 & 5.58 & 7.53 & 13.47 & 5.64 & 7.83 \\
\hline OMW $_{(10 \%)}+$ NPK $_{(50 \%)}$ & 12.89 & 4.23 & 8.66 & 13.09 & 4.4 & 8.69 \\
\hline $\operatorname{OMW}_{(10 \%)}+\operatorname{NPK}_{(75 \%)}$ & 12.51 & 4.41 & 8.1 & 12.81 & 4.51 & 8.31 \\
\hline $\operatorname{OMW}_{(10 \%)}+$ Biochar $\operatorname{NPK}_{(50 \%)}$ & 13.31 & 5.98 & 7.33 & 13.16 & 6.08 & 7.08 \\
\hline $\operatorname{OMW}_{(10 \%)}+$ Biochar NPK $(75 \%)$ & 13.66 & 6.01 & 7.65 & 13.82 & 6.31 & 7.51 \\
\hline Mean & 13.09 & 5.15 & 7.93 & 13.33 & 5.32 & 7.89 \\
\hline OMW $_{(20 \%)}+$ NPK $_{(50 \%)}$ & 12.15 & 4.5 & 7.65 & 12.20 & 5.01 & 7.19 \\
\hline OMW $_{(20 \%)}+\operatorname{NPK}_{(75 \%)}$ & 12.98 & 4.79 & 8.19 & 13.03 & 5.32 & 7.71 \\
\hline OMW $_{(20 \%)}+$ Biochar + NPK $_{(50 \%)}$ & 13.50 & 6.01 & 7.49 & 13.84 & 6.23 & 7.61 \\
\hline OMW $_{(20 \%)}+$ Biochar + NPK $_{(75 \%)}$ & 13.88 & 6.33 & 7.55 & 13.98 & 6.44 & 7.54 \\
\hline Mean & 13.12 & 5.40 & 7.72 & 13.26 & 5.75 & 7.51 \\
\hline \multicolumn{7}{|l|}{ LSD. at 0.05} \\
\hline Treatment & 2.72 & 3.93 & 1.57 & 2.32 & 4.23 & 2.34 \\
\hline OMW Rates & 1.93 & 2.19 & 1.38 & 1.51 & 3.41 & 1.91 \\
\hline Biochar & 1.95 & 3.26 & 1.49 & 1.81 & 3.51 & 1.59 \\
\hline
\end{tabular}

2. Effect of olive mill wastewater and boichar combined with different NPK rate on soil chemical properties.

\subsection{Soil pH}

Data in Table 5 showed that soil $\mathrm{pH}$ values decrease slightly and moderate with application of biochar and olive wastes water (OMW) at two rates $10 \%$ and $20 \%$ with NPK rates $(50 \%, 75 \%$ recommended dose), the decrease of soil $\mathrm{pH}$ was not significantly in both season, where the best value of soil $\mathrm{pH}$ was at first season with treated $\mathrm{OMW}_{(20 \%)}+$ biochar $_{(4 \text { ton/fed })}+$ NPK ${ }_{(75 \%)}$ more than other 
treatments. These results are in agreement with Magdich et al. (2013) who reported that the soil pH at soil treated with OMW, was noted to decrease in comparison with the control, which could presumably be attributed to the acidic nature of OMW. In the same trend with Biochar agreement by Simon et al. (2019) who found that the biochar combined with nitrogen mineral rates was slightly reduced the $\mathrm{pH}$ by 0.22 than biochar alone. Albert and Kwame (2018) suggested that the added Biochar as soil amended level reduce $\mathrm{pH}$. Reduction in soil $\mathrm{pH}$ may be related to the residual organic matter after different biochemical and chemical changes.

\subsection{EC value}

Data in Table 5 showed that the electric conductivity (EC) values were affected by all treatments, where low EC values were with treatment of Biochar (4 ton/fed) and olive wastes water with two rates $(10 \%$ and $20 \%)$ combined with NPK $(50 \%, 75 \%)$ in both season. The low EC value was (1.04) $\left(\mathrm{dSm}^{-1}\right)$ at second season compared with other treatments. These result agree with Jones et al. (2011) who reported that the applying of biochar together with $\mathrm{N}$ fertilizer led to decrease soil salinity (EC). These results may be due to that biochar application has reduced soil bulk density and improved soil aggregate structure, which led to increase total porosity in soil and increase in macro pores and in turn to increased water content at low suction pressures led to movement of leaching water that enhance progressive removal for Na-salts (Lei \& Zhang, 2013).

\subsection{Organic matter}

Data in Table 5 showed that organic matter(OM) increased by different treatments application in the soil, organic matter values significantly increased with addition of biochar (4 ton/fed)+ olive wastes water at two rates $10 \%$ and $20 \%$ combined with NPK $(50 \%, 75 \%)$ in both seasons. The highest values of organic matter were $(0.81 \%)$ at first season and $(0.83 \%)$ at second season with $\operatorname{OMW}(20 \%)+$ Biochar $(4$ ton/fed $)+\operatorname{NPK}(75 \%)$ application more than other treatments. The increase in organic matter following biochar application could be due to high carbon (C) associated with biochar (Abdulaziz, 2018). While Several studies showed an increase in organic matter content, total $\mathrm{N}$ and $\mathrm{C} / \mathrm{N}$ ratio following irrigation with OMW and may have a beneficial effect on soil fertility (Mekki et al., 2006; Brunetti et al., 2007; Mekki et al., 2013).

Table 5: Effect of olive mill wastewater and boichar combined with different NPK rate on soil $\mathrm{pH}$, $\mathrm{EC}$ and $\mathrm{OM}$ of two seasons in tested soil.

\begin{tabular}{|c|c|c|c|c|c|c|}
\hline \multirow[b]{2}{*}{ Treatments } & \multicolumn{3}{|c|}{ First season } & \multicolumn{3}{|c|}{ Second season } \\
\hline & pH & $\begin{array}{c}\mathrm{EC} \\
\left(\mathrm{dSm}^{-1}\right)\end{array}$ & $\begin{array}{l}\text { OM } \\
(\%)\end{array}$ & pH & $\begin{array}{c}\mathrm{EC} \\
\left(\mathrm{dSm}^{-1}\right)\end{array}$ & $\begin{array}{l}\text { OM } \\
(\%)\end{array}$ \\
\hline Control (NPK) (100\%) & 7.80 & 1.29 & 0.50 & 7.81 & 1.31 & 0.52 \\
\hline $\operatorname{Biochar}_{(4 \mathrm{ton} / \mathrm{fed})}+\mathbf{N P K}_{(\mathbf{5 0} \%)}$ & 7.71 & 1.15 & 0.52 & 7.73 & 1.13 & 0.54 \\
\hline $\operatorname{Biochar}_{(4 t o n / f e d)}+\operatorname{NPK}_{(75)}$ & 7.73 & 1.18 & 0.50 & 7.70 & 1.15 & 0.53 \\
\hline Mean & 7.72 & 1.16 & 0.51 & 7.71 & 1.14 & $\mathbf{0 . 5 3}$ \\
\hline $\mathrm{OMW}_{(10 \%)}+\mathrm{NPK}_{(75 \%)}$ & 7.71 & 1.17 & 0.52 & 7.72 & 1.16 & 0.50 \\
\hline $\mathrm{OMW}_{(10 \%)}+$ Biochar + NPK $_{(50 \%)}$ & 7.63 & 1.16 & 0.56 & 7.63 & 1.15 & 0.57 \\
\hline $\mathrm{OMW}_{(10 \%)}+$ Biochar $+\operatorname{NPK}_{(75 \%)}$ & 7.61 & 1.15 & 0.57 & 7.59 & 1.14 & 0.58 \\
\hline Mean & 7.64 & 1.172 & 0.54 & 7.66 & 1.1625 & 0.54 \\
\hline $\mathrm{OMW}_{(20 \%)}+\mathrm{NPK}_{(50 \%)}$ & 7.71 & 1.20 & 0.56 & 7.72 & 1.19 & 0.58 \\
\hline Mean & 7.66 & $\mathbf{1 . 1 7 5}$ & 0.55 & 7.65 & 1.167 & 0.56 \\
\hline \multicolumn{7}{|l|}{ LS.D. at 0.05} \\
\hline Treatment & 0.04 & 0.14 & 0.08 & 0.05 & 0.18 & 0.09 \\
\hline OMW Rates & 0.16 & 0.12 & 0.051 & 0.14 & 0.14 & 0.04 \\
\hline Biochar & 0.08 & 0.13 & 0.01 & 0.06 & 0.17 & 0.01 \\
\hline
\end{tabular}




\section{Available of macronutrient content in soil.}

Data presented in Table 6 showed that the available macronutrients i.e.( $\mathrm{N}, \mathrm{P}$ and $\mathrm{K} \mathrm{mg} / \mathrm{kg}$ soil) as affected by all treatments, where the positive effect was achieved under all treatments compared with control. Generally, data showed that the available N, P, and $\mathrm{K}$ in soil were significantly enhanced by using treatments $\operatorname{biochar}_{(4 \text { ton/ed) }}$ and Olive mill wastewater with two rates $(10 \%, 20 \%)$ compared with control NPK ${ }_{(100 \%)}$ of recommended dose. The highest values of N, P and K contents in soil were $48.1,5.62$ and $183 \mathrm{mg} / \mathrm{kg}$ soil respectively, at first season and $48,9,6.3$ and $184 \mathrm{mg} / \mathrm{kg}$ soil respectively, at second season for soil treated by $\mathrm{OMW}_{(20 \%)}+$ Biochar $(4$ ton/fed) + NPK $(75 \%)$ than other treatments. These results are in agreement with those reported by Barbera et al. (2014) who mentioned that olive mill wastewater helps in fixing $\mathrm{N}_{2}$, solubilizing mineral phosphates and other nutrients. Increasing the soil content of $\mathrm{N}, \mathrm{P}$ and $\mathrm{K}$ due to the application of organic fertilizers might be a result of its decomposition and producing organic acids, which increases the nutrients availability in the soil. Also, reported Liang et al. (2006) indicated that addition of biochar led to increased contents of N, P and $\mathrm{K}$ in soil. Biochar addition to soil led to an increase of organic matter, water holding capacity, nutrient retaining capacity, and bioavailability nutrition elements (e.g., N, P, K, Ca) in soil (Ouyang et al., 2013).

Table 6: Effect of olive mill wastewater and boichar combined with different NPK rate of NPK in two seasons in tested soil.

\begin{tabular}{|c|c|c|c|c|c|c|}
\hline \multirow{2}{*}{ Treatments } & \multicolumn{3}{|c|}{ First season (mg Kg-1soil) } & \multicolumn{3}{|c|}{ Second season (mg Kg-1soil) } \\
\hline & $\mathbf{N}$ & $\mathbf{P}$ & $\mathbf{K}$ & $\mathbf{N}$ & $\mathbf{P}$ & $\mathbf{K}$ \\
\hline Control (NPK) $(100 \%)$ & 41.4 & 4.1 & 174 & 40.1 & 5.2 & 171 \\
\hline Biochar + NPK $(50 \%)$ & 44.2 & 4.99 & 177.0 & 43.3 & 4.8 & 180 \\
\hline Biochar + NPK $(75)$ & 44.8 & 5.20 & 179.0 & 45.1 & 5.3 & 174 \\
\hline Mean & 44.5 & 5.19 & 178.0 & 44.2 & 5.75 & 177 \\
\hline $\mathbf{O M W}_{(10 \%)}+\mathrm{NPK}_{(50 \%)}$ & 39.9 & 4.44 & 169.0 & 40.2 & 5.4 & 174 \\
\hline $\mathbf{O M W}_{(10 \%)}+\mathrm{NPK}(75 \%)$ & 40.1 & 4.6 & 173.0 & 40.5 & 5.45 & 170 \\
\hline OMW $_{(10 \%)}+$ Biochar $+\operatorname{NPK}_{(50 \%)}$ & 44.3 & 5.20 & 175.0 & 45.1 & 6.12 & 176 \\
\hline OMW $_{(10 \%)}+$ Biochar NPK $_{(75 \%)}$ & 46.9 & 5.56 & 181.0 & 47.1 & 6.2 & 182 \\
\hline Mean & 42.1 & 4.95 & $\mathbf{1 7 4 . 5}$ & 43.22 & 5.79 & 175.5 \\
\hline $\mathbf{O M W}_{(20 \%)}+\mathrm{NPK}_{(50 \%)}$ & 39.9 & 4.57 & 171.0 & 40.8 & 5.7 & 172 \\
\hline $\mathbf{O M W}_{(20 \%)}+\mathrm{NPK}_{(75 \%)}$ & 41.8 & 4.85 & 176.0 & 42.3 & 5.9 & 177 \\
\hline OMW $_{(20 \%)}+$ Biochar $+\operatorname{NPK}_{(50 \%)}$ & 46.1 & 5.45 & 179.0 & 47.3 & 5.91 & 180 \\
\hline $\mathbf{O M W}_{(20 \%)}+$ Biochar $+\operatorname{NPK}_{(75 \%)}$ & 48.1 & 5.62 & 183.0 & 48.9 & 6.3 & 184 \\
\hline Mean & 43.9 & 5.12 & 177.3 & 44.82 & 6.2 & 178.25 \\
\hline \multicolumn{7}{|l|}{ LSD. at 0.05} \\
\hline Treatment & 2.6 & 0.77 & 3.33 & 2.34 & 0.75 & 2.3 \\
\hline OMW Rates & 2.55 & 0.76 & 3.27 & 2.31 & 0.61 & 3.31 \\
\hline Biochar & 2.19 & 0.70 & 2.09 & 1.71 & 0.58 & 2.08 \\
\hline
\end{tabular}

\section{NPK Contents in seeds of peanut.}

Data presented in Table 7 the concentration of macronutrients i.e., N, P and K in the studied seed under the effect of different treatments. Data show that the increasing of available N, P, and K concentrations in seed as significantly by using treatments biochar ( 4 ton/fed) and Olive mill wastewater with two rates compared with control $\mathrm{NPK}_{(100 \%)}$. The highest values of N, P and K contents in seeds were 4.90, 0.56 and $1.096 \%$ seed at first season and 4.97,0.59 and 1.11(g plant-1) seed at second season for plant treated by $20 \%$ OMW $+75 \%$ NPK + biochar than other treatments. These results are in agreement with those reported by Laird et al. (2010) who showed biochar (4 ton/fed) was responsible improve nutrient status content in plant. Therefore, $\mathrm{N}$ and $\mathrm{P}$ availability could be expected to increase with biochar application rather than responsible improve crop growth and nutrient status. In the same trend Lesage-Meessen et al. (2001) reported that some OMW characteristics are favorable for agriculture since this effluent is rich in water, organic matter, nitrogen, phosphorous, potassium and magnesium. In line with this finding Osama and Wolfgang (2019) metioned that Olive mill wastewater (OMW) application increased the soil nutrient contents due to its richness in nutrient $\mathrm{N}, \mathrm{P}, \mathrm{K}$ concentration in plant.. 
Table 7: Effect of olive mill wastewater and boichar combined with different NPK rate on NPK content in seeds.

\begin{tabular}{|c|c|c|c|c|c|c|}
\hline \multirow{2}{*}{ Treatments } & \multicolumn{3}{|c|}{ First season(g plant-1) } & \multicolumn{3}{|c|}{ Second season(g plant-1) } \\
\hline & $\mathbf{N}$ & $\mathbf{P}$ & $\mathbf{K}$ & $\mathbf{N}$ & $\mathbf{P}$ & $\mathbf{K}$ \\
\hline Control (NPK) (100\%) & 3.77 & 0.30 & 0.45 & 3.81 & 0.32 & 0.47 \\
\hline Biochar + NPK $(50 \%)$ & 4.83 & 0.51 & 0.94 & 4.87 & 0.52 & 0.95 \\
\hline Biochar + NPK $(75)$ & 4.89 & 0.54 & 0.96 & 4.91 & 0.53 & 0.98 \\
\hline Mean & 4.86 & 0.52 & 0.95 & 4.89 & 0.52 & 0.96 \\
\hline OMW $_{(10 \%)}+\operatorname{NPK}_{(50 \%)}$ & 4.15 & 0.34 & 0.951 & 4.19 & 0.35 & 0.93 \\
\hline $\operatorname{OMW}_{(10 \%)}+\operatorname{NPK}_{(75 \%)}$ & 4.22 & 0.36 & 0.940 & 4.21 & 0.37 & 0.97 \\
\hline OMW $_{(10 \%)}+$ Biochar $+\operatorname{NPK}_{(50 \%)}$ & 4.85 & 0.52 & 0.991 & 4.91 & 0.51 & 1.03 \\
\hline OMW $_{(10 \%)}+$ Biochar NPK $_{(75 \%)}$ & 4.89 & 0.58 & 1.01 & 4.94 & 0.55 & 1.04 \\
\hline Mean & 4.52 & 0.45 & 0.97 & 4.56 & 0.44 & 0.99 \\
\hline $\mathrm{OMW}_{(20 \%)}+\mathrm{NPK}_{(50 \%)}$ & 4.51 & 0.41 & 0.97 & 4.53 & 0.44 & 0.983 \\
\hline $\operatorname{OMW}_{(20 \%)}+\operatorname{NPK}_{(75 \%)}$ & 4.68 & 0.42 & 0.95 & 4.61 & 0.46 & 0.987 \\
\hline OMW $_{(20 \%)}+$ Biochar $+\operatorname{NPK}_{(50 \%)}$ & 4.85 & 0.55 & 1.01 & 4.93 & 0.54 & 1.02 \\
\hline OMW $_{(20 \%)}+$ Biochar $+\operatorname{NPK}_{(75 \%)}$ & 4.90 & 0.56 & 1.09 & 4.97 & 0.59 & 1.11 \\
\hline Mean & 4.73 & 0.48 & 1.005 & 4.76 & 0.50 & 1.02 \\
\hline \multicolumn{7}{|l|}{ LSD. at 0.05} \\
\hline Treatments & 1.58 & 0.25 & 0.476 & 1.87 & 0.21 & 0.671 \\
\hline OMW rates & 1.08 & 0.19 & 0.55 & 1.35 & 0.18 & 0.55 \\
\hline Biochar & 1.59 & 0.25 & 0.56 & 1.88 & 0.22 & 0.49 \\
\hline
\end{tabular}

\section{Plant growth}

Results in Table 8 revealed that there are significant effect by the biochar $(4$ ton/fed $)$ and Olive wastewater with two rates $10 \%$ and $20 \%$ treatments on all studied traits of plant growth in both seasons compared with $\mathrm{NPK}_{(100 \%)}$ of recommended dose. The maximum values of Plant height $(\mathrm{cm})$, number of branches/plant and number of pods/Plant were $79.6 \mathrm{~cm} 6.99$ and 20.66 respectively, in second season were achieved with 20\% OMW $+75 \%$ NPK + biochar application than other treatments at first season. These results are agreement with Boz et al. (2009) who reported that using OMW to soil led to increase of crops yields. Sasanelli et al. (2011) reported OMW can improve plant growth which may be due to resistance to photo- pathogens attack by stimulating root development and large content of nutritive elements and biocide compounds. El-Abbassi et al. (2017) reported that Olive wastewater (OMW) increase the plant growth reflected to of the main bacterial, fungal photo-pathogens, and weed species without any negative. Biochar amendment application improved peanut biomass and pod yield in both seasons.

\section{Yield and yield components}

Results in Table 9 showed that Yield and yield components were affected by the biochar and Olive mill wastewater with two rates $10 \%$ and $20 \%$ with $\mathrm{NPK}_{(100 \%)}$ application, where the characters seeds yield, seeds protein (\%) and Seeds oil(\%), components in both seasons were improved compared with control. Where, the highest values of seeds yield $(\mathrm{kg} / \mathrm{fed})$, seeds protein $(\%)$ and Seeds oil(\%)were achieved with treated by $20 \%$ OMW $+75 \%$ NPK + biochar than other treatments at first season as follow $1330.54(\mathrm{~kg} / \mathrm{fed}), 31.75 \%$ and $44.03 \%$, respectively. The same in second season $1332.52(\mathrm{~kg} / \mathrm{fed}), 32.03 \%$ and $44.05 \%$, respectively. This result agreement with Belaqziz et al. (2008); Mahmoud et al. (2010) reported that using OMW to soil led to increase of crops yields. Biochar amendment application was improved peanut biomass and pod yield in both seasons. The significant yield increase in peanut in response to the application of biochar to soil was significant increase of yield peanut (Liu et al., 2013). Biederman and Harpole (2013) reported Biochar was improved the biomass and pod yield of peanut and enhance leaf photosynthetic rate and crop production. 
Table 8: Effect of olive mill wastewater and boichar combined with different NPK rate on plant height, No. of branches and No. of pods in peanut plant.

\begin{tabular}{|c|c|c|c|c|c|c|}
\hline \multirow[b]{2}{*}{ Treatments } & \multicolumn{3}{|c|}{ First season } & \multicolumn{3}{|c|}{ Second season } \\
\hline & $\begin{array}{c}\text { Plant } \\
\text { height } \\
\text { (cm) }\end{array}$ & $\begin{array}{c}\text { No. of } \\
\text { branches/plant }\end{array}$ & $\begin{array}{c}\text { No. } \\
\text { of } \\
\text { pods/ } \\
\text { plant }\end{array}$ & $\begin{array}{c}\text { Plant } \\
\text { height } \\
\text { (cm) }\end{array}$ & $\begin{array}{c}\text { No. of } \\
\text { branches/plant }\end{array}$ & $\begin{array}{c}\text { No. of } \\
\text { pods/ } \\
\text { plant }\end{array}$ \\
\hline Control (NPK) (100\%) & 62.7 & 4.5 & 17.71 & 63.7 & 4.3 & 16.23 \\
\hline Biochar + NPK $(50 \%)$ & 74.3 & 6.11 & 19.81 & 74.8 & 6.12 & 19.94 \\
\hline Biochar + NPK $(75)$ & 75.2 & 6.17 & 19.99 & 75.7 & 6.19 & 20.1 \\
\hline Mean & 74.75 & 6.14 & 19.9 & 75.25 & 6.15 & 20.02 \\
\hline $\mathbf{O M W}_{(10 \%)}+\mathbf{N P K}_{(50 \%)}$ & 66.7 & 5.091 & 18.23 & 66.9 & 5.23 & 18.45 \\
\hline OMW $_{(10 \%)}+\operatorname{NPK}_{(75 \%)}$ & 67.3 & 5.41 & 18.55 & 67.7 & 5.45 & 18.61 \\
\hline OMW $_{(10 \%)}+$ Biochar + NPK $(50 \%)$ & 75.1 & 6.49 & 19.73 & 78.3 & 6.55 & 20.281 \\
\hline OMW $_{(10 \%)}+$ Biochar NPK $_{(75 \%)}$ & 77.5 & 6.61 & 20.92 & 78.9 & 6.63 & 20.51 \\
\hline Mean & 71.55 & 5.90 & 19.35 & 72.95 & 5.96 & \\
\hline $\mathrm{OMW}_{(20 \%)}+\mathrm{NPK}_{(50 \%)}$ & 70.2 & 5.82 & 19.31 & 70.9 & 5.86 & 19.37 \\
\hline OMW $_{(20 \%)}+$ NPK $_{(75 \%)}$ & 71.8 & 5.91 & 19.43 & 72.4 & 5.92 & 19.47 \\
\hline OMW $(20 \%)+$ Biochar + NPK $(50 \%)$ & 76.7 & 6.94 & 20.51 & 78.8 & 6.97 & 20.53 \\
\hline OMW $(20 \%)+$ Biochar + NPK $(75 \%)$ & 77.7 & 6.987 & 20.59 & 79.6 & 6.998 & 20.66 \\
\hline Mean & 74.05 & 6.41 & 19.96 & 75.42 & 6.43 & \\
\hline LSD. at 0.05 & & & & & & \\
\hline Treatments & 14.87 & 2.49 & 2.29 & 15.9 & 2.70 & 4.49 \\
\hline OMW Rates & 11.35 & 1.92 & 1.77 & 11.55 & 2.14 & 2.79 \\
\hline BIochar & 8.509 & 1.65 & 2.301 & 11.74 & 1.87 & 2.41 \\
\hline
\end{tabular}

Table 9: Effect of olive mill wastewater and boichar combined with different NPK rate on yield components

\begin{tabular}{|c|c|c|c|c|c|c|}
\hline \multirow[b]{2}{*}{ Treatments } & \multicolumn{3}{|c|}{ First season } & \multicolumn{3}{|c|}{ Second season } \\
\hline & $\begin{array}{c}\text { Seeds } \\
\text { yield } \\
\text { (kg/fed) }\end{array}$ & $\begin{array}{c}\text { Seeds } \\
\text { protein } \\
(\%) \\
\end{array}$ & $\begin{array}{c}\text { Seeds } \\
\text { oil } \\
(\%) \\
\end{array}$ & $\begin{array}{c}\text { seeds } \\
\text { yield } \\
(\mathrm{kg} / \text { fed })\end{array}$ & $\begin{array}{c}\text { Seeds } \\
\text { protein } \\
(\%) \\
\end{array}$ & $\begin{array}{c}\text { Seeds } \\
\text { oil } \\
(\%) \\
\end{array}$ \\
\hline Control (NPK) (100\%) & 1011.76 & 23.56 & 37.01 & 1011.91 & 23.81 & 37.98 \\
\hline Biochar + NPK $(50 \%)$ & 1233.1 & 30.18 & 42.61 & 1233.87 & 30.43 & 42.73 \\
\hline Biochar + NPK & 1234.19 & 30.56 & 42.81 & 1234.33 & 30.68 & 42.87 \\
\hline Mean & 1233.64 & 30.37 & 42.71 & 1234.1 & 30.56 & 42.81 \\
\hline $\mathrm{OMW}_{(10 \%)}+\mathrm{NPK}_{(50 \%)}$ & 1100.45 & 25.93 & 39.21 & 1130.81 & 26.18 & 39.43 \\
\hline $\operatorname{OMW}_{(10 \%)}+\operatorname{NPK}_{(75 \%)}$ & 1189.21 & 26.37 & 39.98 & 1201.31 & 26.93 & 40.3 \\
\hline OMW $_{(10 \%)}+$ Biochar $+\operatorname{NPK}_{(50 \%)}$ & 1320.21 & 31.56 & 43.01 & 1321.71 & 30.75 & 42.97 \\
\hline OMW $_{(10 \%)}+$ Biochar NPK $_{(75 \%)}$ & 1322.43 & 32.06 & 43.66 & 1323.61 & 31.18 & 43.44 \\
\hline Mean & 1233.075 & 29.25 & 41.75 & $\mathbf{1 2 4 4 . 2 5}$ & 29.25 & 41.75 \\
\hline $\mathrm{OMW}_{(20 \%)}+\mathrm{NPK}_{(50 \%)}$ & 1225.76 & 28.81 & 41.57 & 1226.61 & 28.93 & 41.66 \\
\hline $\operatorname{OMW}_{(20 \%)}+\operatorname{NPK}_{(75 \%)}$ & 1227.17 & 29.25 & 41.73 & 1228.19 & 29.43 & 41.84 \\
\hline OMW $_{(20 \%)}+$ Biochar $+\operatorname{NPK}_{(50 \%)}$ & 1328.94 & 31.51 & 42.93 & 1329.1 & 31.96 & 43.22 \\
\hline OMW $_{(20 \%)}+$ Biochar NPK $_{(75 \%)}$ & 1330.54 & 31.75 & 44.03 & 1332.52 & 32.03 & 44.05 \\
\hline Mean & 1277.58 & 30.75 & 42.75 & $\mathbf{1 2 7 9 . 5 5}$ & 30.75 & 43.1 \\
\hline \multicolumn{7}{|l|}{ LSD. at 0.05} \\
\hline Treatments & 318.73 & 8.91 & 7.81 & 320.61 & 8.22 & 6.81 \\
\hline OMWRates & 262.47 & 7.77 & 5.15 & 267.59 & 6.77 & 5.05 \\
\hline Biochar & 222.49 & 4.83 & 3.71 & 222.47 & 4.83 & 3.71 \\
\hline
\end{tabular}

\section{Conclusions}

Olive mill wastewater and biochar constitutes a serious environmental problem. Several physical, chemical and biological processes to reduce their contaminant impacts have been proposed. Many researchers have established that this wastewater have a high fertilizer value when applied to the soil. 
Soils in semi-arid and arid areas are known to have low organic matter levels, a low fertility and a high exposure to degradation, desertification and pollution. Currently, organic wastes of various origins and nature are widely used as amendments to increase soil organic matter and crop productivity.

The peanut plant is an important food and oilseed crop, it is called as the king of oilseeds crops. We indicated the results of physical and chemical factors and biochar-associated organic compounds associated by application of OMW and biochar can improve soil quality indices nutrients $(\mathrm{N}, \mathrm{P}$, and $\mathrm{K}$ ), organic matter and $\mathrm{pH}$. Biochar amendment application improved peanut biomass and pod yield in both seasons. The significant yield increase in peanut in response to the application of OMW + biochar combined with NPK to soil was significant increase of yield peanut compared with control.

\section{Reference}

Abdelraouf, R., E. Essay and M. Saleh, 2017. Sustainable management of deficit irrigation in sandy soils by production biochar and adding it as a soil amendment. Middle East J. of Agric. Res., 6 (4): 1359- 1375.

Abd El-Hadi, 2004. Country Report on Egytian Agriculture. IPI regional workshop on Potassium and Fertigation development in West Asia and North Africa; Rabat, Morocco. November, 24-28.

Abdulaziz, G.A., 2018 Biochar as a potential soil additive for improving soil physical properties-a review. Arabian Journal of Geosciences, 11: 766

Adnan, K., and Ghaida Abu-Rumman, 2015. Effect of Olive Mills Wastewater (OMWW) on Soil Thermal Conductivity.International Journal of Soil Science, 10 (2): 84-92.

Ahmed, A. Z., K. Vasiliki, D. Charalampos, G. Mary-Lorène, J. Salah, G. Camelia Matei, 2020. Olive mill wastewater: From a pollutant to green fuels, agricultural and water source and biofertilizer - Hydrothermal carbonization. Science, 733:139314.

Albert, K., and A. Kwame, 2018 Biochar and or compost applications improve soil properties, growth and yield of maize grown in Acidic rainforest and coastal savannah soils in Ghana, Research Article. Inter. J. of Agron. 6 - 8.

Alburquerque, J., J. Calero, V. Barrón, J. Torrent, M. Campillo, A. Gallardo, R. Villar, 2014. Effects of biochars produced from different feedstocks on soil properties and sunflower growth. Journal of Plant Nutrition and Soil Science, 177: 16-25.

Arvidsson, J., 1999. Nutrient uptake and growth of barley as affected by soil compaction. Plant Soil, 208: 9-19.

Atanu, M., and L. Rattan, 2013. Biochar Impacts on Soil Physical Properties and Greenhouse Gas Emissions. Review Agronomy, 3: 313-339;

Belaqziz, M., E.K. Lakhal, H. Mbouobda, and I. El-Hadrami, 2008. Land spreading of olive mill wastewater: effect on maize (Zea maize). Journal of Agronomy, 7: 297 -305.

Barbera A., C. Maucieri, V. Cavallaro, A. Ioppolo, and G. Spagna, 2013. Effects of olive mill wastewater on soil properties and crops, a review Agric. Water Manage, 119: 43-10.

Barbera A., C. Maucieri, A. Ioppolo, M. Milani, V. Cavallaro, 2014. Effects of olive mill wastewater physic-chemical treatments on polyphenol abatement and Italian ryegrass (Lolium multiflorum Lam.) germinability. Water Res., 52: 275-276.

Belqziz, M., A. El-Addassi, E. Lakhal, E. Agrafioti, and C. Galanakis, 2016. Agronomic application of olive mill wastewater: effect on maize production and soil properties. Journal of Environmental Management, 171: 158-165.

Biederman, L.A. and W.S. Harpole, 2013. Biochar and its effects on plant productivity and nutrient cycling: a meta-analysis Glob. Change Biol., 5: 202-214.

Black, G.R., D.D. Evans, L.E. Ensminger, J.L. White, and F.E. Chark, 1965. Methods of soil analysis, Agron. Series, AM. Agron., Madison, Wisconsin, USA.

Boz, O., D. Ogüt, K. Kır, and M. Doğan, 2009. Olive Processing Waste as a Method of Weed Control for Okra, Faba Bean, and Onion. Weed Technology 23:569-573 .

Brunetti G, N. Senesi and C. Plaza, 2007. Effects of amendment with treated and untreated olive oil mill wastewaters on soil properties, soil humicsubstances and wheat yield. Geoderma, 138: 144-152. 
Brunner, P., and H. Wasmer, 1978. Methods of analysis of sewage sludge solids wastes and compost. WHO international Reference Centerfor wastes Disposal. Ch-8600 Dubendorf, Switzerland.

Chapman, H. and P. Pratt, 1978. Methods of Analysis for Soils, Plants and Waters. Univ. California Div. Agric. Sci. Priced Publication, Oakland.

Chan, K., L. van Zwieten, I. Meszaros, A. Downie and S. Joseph, 2007. Agronomic values of green waste biochar as a soil amendment. Australian Journal of Soil Research, 45: 629-634.

Duarte, S., G. Bruno, and E. Carlos, 2019. Effect of biochar particle size on physical, hydrological and chemical properties of loamy and sandy tropical soils. J. Agronomy. 9: 1- 15.

Dumroese, R.K., J. Heiskanen, K. Englund, and A. Tervahauta, 2011. Pelleted biochar: chemical and physical properties show potential use as a substrate in container nurseries. Biomass and Bioenergy, 35(5):2018-2027.

El-Abbassi, A., N. Saadaoui, H. Kiai, J. Raiti, and A. Hafidi, 2017. Potential applications of olivemill wastewater as biopesticide for crops protection. Science of Total Environment, 576: 10-21.

FAO, 2016. Recommended citation: AQUASTAT Country Profile-Egypt. Food and Agriculture Organization of the United Nations (FAO). Rome, Italy

Giovanna C., L. Giovanni, and C. Leonardo, 2008. Improvement of soil properties by application of olive oil waste.Agron. Sustain. Dev., 28: 521-526.

Gomez, K.A., and A.A. Gomez, 1984. Statistics for Agriculture Research. $2^{\text {nd }}$ Ed. John Willey and sons, New York, USA

Idriss, M.A., 2004. The Ability of Some Thermo- Alkalophilic Bacillus Species to Fix Nitrogen, Isolated from MadinahMunawwarah Soils, Saudi Arabia J. Jkau Sci., 16: 3-8.

Jones, D., J. Rousk, G. Edwards-Jones, T. DeLuca, and D. Murphy, 2011. Biochar-mediated changes in soil quality and plant growth in a three-year field trial. Soil Biol. Biochem., 12: 1- 10.

Kavvadias, V., M. Doula, M. Papadopoulou, and S. Theocharopoulos, 2015. Long-term application of olive-mill wastewater affects soil chemical and microbial properties. Soil Research, 53: 461473.

Khaled, D.A., and J.S. Jeff, 2019. Addition of biochar to a sandy desert soil: Effect on crop growth, water retention and selected properties. J. Agronomy., 9 (327):1-24.

Laird, D., P. Fleming, B. Wang, R. Horton, and D. Karlen, 2010. Biochar impact on nutrient leaching from a midwestern agricultural soil. Geoderma. doi:10.1016/j.

Lehmann, J. and S. Joseph, 2009. Biochar for environmental management: an introduction. In: J. Lehmann, S. Joseph. (eds.), Biochar for Environmental Management: Sci. and Technology, Earthscan, London. 1-12.

Lei, O. and R. Zhang, 2013. Effects of biochars derived from different feedstocks and pyrolysis temperatures on soil physical and hydraulic properties. Journal of Soils and Sediments, 13(9):1561-1572.

Leonard, G., 2013. Effect of biochar application rate on soil physical and hydraulic properties of a sandy loam.Archives of Agronomy and Soil Sci. 27: 37- 41.

Lesage-Meesen, L., D. Navarro, S. Maunier, J.C. Sigoillot, J. Lorquin, M. Delattre, J.L. Simon, M. Asther, and M. Labat, 2001. Simple phenolic content in olive oil residues as a function of extraction systems, Food Chem., 75:501.

Liang, B., J. Lehmann, D. Solomon, J. Kinyangi, B. Grossman, J. O'Neill, O. Skjemstad, J. Thies, F. Luizão, J. Petersen, and E. Neves, 2006. Black carbon increases cation exchange capacity in soils. Soil Sci. Soc. Am. J., 70:1719-1730.

Liu, X.Y., A.F. Zhang, C.Y. Ji, S. Joseph, R.J. Bian, L.Q. Li, G.X. Pan and J. Paz-Ferreiro, 2013. Biochar's effect on crop productivity and the dependence on experimental conditions-a metaanalysis of literature data. Plant Soil, 373: 583-594.

Magdich, S., C.B. Ahmed, R. Jarboui, B.B. Rouina, M. Boukhris, and E. Ammar, 2013. Dose and frequency dependent effects of olive mill wastewater treatment on the chemical and microbial properties of soil. Chemosphere, 93 (9).

Mahmoud, M., M. Janssen, N. Haboub, A. Nassour, and B. Lennartz, 2010.The impact of olivemill waste water application on flow and transport properties in soils. Soil and Tillage Research, 107: $36-41$.

Mekki A, A. Dhouib and S. Sayadi 2006. Changes in microbial and soil properties following amendment with treated and untreated olive mill wastewater. Microbiol. Res., 161: 93-101. 
Mekki, A., A. Dhouib, and S. Sayadi, 2013. Effects of olive mill wastewater application on soil properties and plants growth. International Journal of Recycling of Organic, Waste in Agriculture, 2(1): 1-7.

Mohawesh, O., M. Mahmoud, M. Janssen, and B. Lennartz, 2014.Effect of irrigation with olive mill wastewater on soil hydraulic and solute transport properties. International journal of Environmental Science and Technology, 11: 927-934.

Ndor E., S. Dauda, and E. Azagaku, 2015. Response of Maize Varieties (Zea mays) to Biochar Amended Soil in Lafia, Nigeria. American Journal of Experimental Agriculture 5(6): 525-531.

Novak, J. M., I. Lima, B. Xing, J.W. Gaskin, C. Steiner, K.C. Das, and H.H. Schomberg, 2009b. Characterization of designer biochar produced at different temperatures and their effects on a loamy sand. Annals of Environmental Science, 3: 195-206.

Osama, M., and D. Wolfgang, 2019. Effects of Bentonite, Hydrogel and Biochar Amendments on Soil Hydraulic Properties from Saturation to Oven Dryness. Pedosphere, 29(5): 598-607.

Ouzounidou, G. and M. Asfi, 2012. Determination of olive mill wastewater toxic effects on three mint species grown in hydroponic culture. Journal of Plant Nutrition, 35(5): 726- 738

Ouyang, L., F. Wang, J. Tang, L. Yu, and R. Zhang, 2013. Effect of biochar amendment on soil aggregates and hydraulic properties. J. of Soil Sci. and Plant Nutr., 13 (4): 991- 1002.

Page, A.L., R.H. Miller, and D.R. Keeney, 1982. Methods of soil analysis. II Chemical and Microbiological properties $2^{\text {nd }}$ Ed. Madison, Wisconsim. U.S.A.

Piotrowska, A., G. Iamarino, M.A. Rao, and L. Gianfreda, 2006 Short-Term Effects of Olive Mill Waste Water (OMW) on Chemical and Biochemical Properties of a Semiarid Mediterranean Soil. Soil Biology and Biochemistry, 38: 600-610.

Salimpour, S., K. Khavazi, H. Nadian, H. Besharati and M. Miransari. 2010 Enhancing phosphorous availability to canola (Brassica napus L.) using $\mathrm{P}$ solubilizing and sulfur oxidizing bacteria. Australian J. Crop Sci. 4(5): 330-337.

Sasanelli, N., T. D'Addabbo, and, L. Mancini, 2011. Suppressive effect of composted olive mill wastes soil amendments on the root-knot nematode meloidogyne incognita. Acta Hortic. 229$231 \mathrm{http}: / / \mathrm{dx}$. doi.org/10.17660/ActaHortic.2011.914.41.

Simon, K., L. Hongzhen, L. Jiaxin, B. Hamidou, D. Renjie, and W. Shubio, 2019. Role of nutrient Enriched biochar as a soil amendment during maize growth: Exploring practical alternatives to recycle agricultural residuals and to reduce chemical fertilizer demand. Sustainability J.11: 122.

Sommers, L.E., and D.W. Nelson, 1972.Determination of total phosphorus in soil.A rapid perchloric acid digestion procedure. Soil Sci. Soc. Amer. Proc., (36): 902-90.

Soltanpour, P.N., 1985. Use of ammonium bicarbonate DTPA soil test to evaluate elemental availability and toxicity. Commun. Soil Sci. Plant Anal. 16: 323-318.

Taru, V.B., I.Z. Kyagya, S.I. Mshelia, and E.F. Adebayo, 2008. Economic Efficiency of Resource Use in Groundnut Production in Adamawa State of Nigeria. World Journal of Agricultural Sciences 4 (S): 896-900. ISSN 1817-3047 C IDOSI Publications

USDA, 1962.Soil survey manual. U.S. Dept. of Agric. (USDA), Hand Book No.18. Washington Dc.

$\mathrm{Wu}$, S.C., Y.M. Luo, K.C. Cheung and M.H. Wong, 2006. Influence of bacteria on Pb and $\mathrm{Zn}$ speciation, mobility and bio-availability in soil. Environmental Pollution, 144 (3): $765-773$. 